\title{
"BIG BANG" ENLARGEMENT AND COMMON AGRICULTURAL POLICY REFORM
}

Marko LOVEC, Emil ERJAVEC

Biotechnical Faculty, Ljubljana

UDK: 338.43.02(4-6EU)

Pregledni rad

Primljeno: 6. 9. 2010.

The article analyses the influence of the 2004 enlargement and of the 1998-2002 accession negotiations on the Common Agricultural Policy (CAP) reform. In contrast to the dominant liberal institutional political economy models that explain preenlargement CAP reforms in terms of the negative trade related policy externalities, the common budget expenses and the specific role played by the common institutional setting, a critical realist explanatory model is proposed. In accordance with the model, the reforms were facilitated by the conflicting interests and the differences in capacity of the capital fixed to agricultural production in the member states and the candidate countries. The capacity of the agro-capital is defined by comparing the agricultural production structures, which were in the case of the old member states sustaining high levels of the fixed capital and which were in the case of the candidate countries, on average, underdeveloped and under-capitalized. The model is supported by the empirical analysis of the CAP reform and the accession negotiations process.

Keywords: Common Agricultural Policy, enlargement, CEEC, critical realism

$\triangle \quad$ Marko Lovec, Chair of Agricultural Economics, Policy and Law, University of Ljubljana, Biotechnical Faculty,

Zootechnical Dep., Groblje 3, 1230 Domžale, Slovenia.

E-mail: marko.lovec@gmail.com

\section{INTRODUCTION}

Historically, Common Agricultural Policy (CAP) played the role of the European Communities' single most important redistribution mechanism. By guaranteeing relatively high commodity prices, CAP supported the development of agricultural pro- 
DRUŠ. ISTRAŽ. ZAGREB GOD. 21 (2012), BR. 1 (115),

STR. 219-238

LOVEC, M., ERJAVEC, E. "BIG BANG"... ductivity. On behalf of the common market and common policy financing, member states with the highest agricultural production relative to consumption levels were beneficiaries of CAP (Tracy, 1993).

Compared to EU-15, CEEC's 1 total GDP was about $4 \%$, their total agricultural output around $30 \%$ and the farming population approximately equaled the old EU's 20 million farmers (Gorton and Davidova, 2001). On average, CEEC's agricultural sectors were extensive and underdeveloped (OECD, 2002). Under a high product supports based CAP regime, their agriculture would face substantial financial inflows and productivity increases (Buckwell and Tangermann, 1997; Münch, 2000). From the eighties on, the EU was already coping with excessive production and high costs related to it. Since production exceeding market demand had to be financed through the common budget, increased budget expenses provoked disputes between member states. Furthermore, the dumping of agricultural products on world markets triggered trade wars.

In 1992, a year before enlargement criteria were established in Copenhagen, the Council of Agriculture agreed on a profound CAP reform. "MacSharry's" reform, decreasing institutional prices and introducing compensatory payments, was commonly related to the GATT Uruguay Round Agreement, regulating agricultural subsidies (URAA) (Coleman and Tangermann, 1999; Moyer and Josling, 2002). The Agenda 2000 reform from 1999, when accession negotiations on the agriculture chapter began, and the Mid-Term Review Reform (2003), agreed just after accession negotiations were concluded, phased-out most of the production based supports and instituted direct payments and program-based rural development supports. Following the liberal institutional model based explanation, growing expenses, institutional setting and its changes enabled the building of support for the reform "liberalizing" CAP, with supports, decoupled from the current production now explicitly targeting "new multifunctional" (economic, social and environmental) objectives (Garzon, 2006, 2007, 41; Swinnen, 2008).

We find this interpretation of the reforms problematic. First of all "direct payments" (more than $60 \%$ of post-reform CAP expenses) were nothing else than total historical supports allocated to an individual farm, now paid in the form of a single annual payment. In contrast to CAP's newly declared objectives, there was little change in aggregate agricultural subsidies or their allocation. Thus, the decoupling of supports seemed to merely respond to internal and world productivity pressures on the capital fixed to agricultural production (land, agro-technology, infrastructure), levied by intensive industrial farms (Potter and Tilzey, 2007, 1297-1300). Since new sup- 
DRUŠ. ISTRAŽ. ZAGREB GOD. 21 (2012),

BR. 1 (115)

STR. 219-238

LOVEC, M., ERJAVEC, E.: "BIG BANG".. port mechanisms basically fixed the supports to the agricultural production factors (Schrader, 2000, 231) (H1) the mechanisms reform preserved the interests of the agricultural production based capital, pressured by productivity development and globalization (europeization) of agro-food networks.

New support mechanisms increased price pressures on production. But since CEEC's historical production was relatively high (compared to their GDP based contributions to the common budget) direct payments would still provide for substantial financial transfers to their agricultural sectors (Ackrill, 2003). The European Commission (EC, 2002a) argued that high direct supports would have suboptimal effects for modernization of the CEEC's agriculture. However, the financial discipline principle, applied in a manner of balancing member states' contributions with payments received from the CAP budget, in contrast to achieving extremely little in terms of CAP's general efficiency, severely curbed the CAP based financial transfers to CEECs. In order to respect the financial discipline commitment, CEECs had to comply with provisions limiting the phasing-in of direct payments (Swinnen, 2003). Such multiple-speed development of the CAP was further strengthened by the rural development supports, specifically targeting multifunctional objectives, which demanded for nation$\mathrm{al} /$ regional co-financing and capital intensive programs (EC, 2003). The reason for CEEC's conformity with such arrangement seemed to be the fact that CEEC's agriculture mostly consisted of semi-substantial farms with low capital levels and low returns. Thus (H2) the pre-enlargement reforms accommodated CAP to the relative spatial development of the agro-food capital.

For the liberal institutional model, the EU's institutional setting played a vital role. In the final phase of the negotiations, candidate countries conformed to the arrangement under which the economic position of their agriculture would be only nominally improved (Schrader, 2000, 238). This seemed to be related to the impact that the highly institutionalized debate over the common budget had on the enlargement process (Daugbjerg and Swinbank, 2004). However, as far as CEECs are concerned, the budgetary aspect of the distributional bargaining related to the CAP and the enlargement merely reflected the weak role of CEEC's agricultural production based capital. Thus, (H3) the reform and the enlargement processes were determined by the structural power exerted by the locus of agricultural production dependent capital.

In contrast with the common explanations, the model proposed stresses the importance of the enlargement for understanding the developments in the contemporary CAP. In chapter 2, the standard liberal institutional approach towards the CAP reforms is contrasted with the critical realist approach. 
DRUŠ. ISTRAŽ. ZAGREB GOD. 21 (2012)

BR. 1 (115),

STR. $219-238$

LOVEC, M., ERJAVEC, E. "BIG BANG"..
Chapter 3 establishes structural factors shaping the globalization of the "agricultural welfare state" (H1) and chapter 4 applies the explanation to the case of integration of CEEC $(\mathrm{H} 2)$. Chapter 5 demonstrates how institutionally-specific characteristics of the accession negotiations process were shaped through structure of interests $(\mathrm{H} 3)$. We conclude our text by discussing the implications of our analysis for understanding of the CAP and of the EU project "beyond" the "common" perspectives.

\section{THEORETICAL FRAMEWORK FOR THE RESEARCH}

Following the common argument based on the liberal institutional approach, the modernization of agricultural production raised CAP budget costs and increased negative externalities in terms of distribution of costs between the member states, as regards global trade, development and environment. Different lobbies increased the pressure for liberalization of agricultural production and trade (Daugbjerg, 1997). In addition, new pressure groups emerged in the CAP field (e.g. environmental NGOs), demanding for sustainable agricultural practices and defending traditional family farm based agriculture (Garzon, 2007, 16-7). The 1992-2003 CAP reforms made a distinction between raw agricultural products, the price of which was considered to be left to the market, and "joint-products" of agricultural production practices, such as economic viability of rural areas, animal welfare, protection of animal habitats etc. Since most of the latter were considered to be important public goods, it was decided that they would be supported through modification of the CAP mechanisms (EC, 2003).

New issues and actors as well as global pressures on EU's policies have influenced CAP reforms. Simultaneously, reforms were affected by specific institutional characteristics, defining the EU as a three level (super-state, inter-state and state-level) polity (Moyer and Josling, 2002). EU enlargements in the eighties and nineties have increased the complexity of strategic coalitions made in the European Council, thus increasing the role of the European Commission and its services, claiming to be representing the interests of EU's consumers and taxpayers. The installment of multi-year financial agreements replacing the annual budgets further made the institutional setting more pro-reform biased. Due to the enhanced transparency of financial redistribution and of the common budget related moral hazard, contributors to the common budget pressured for budget stringency (Cunha, 2004; Daugbjerg and Swinbank, 2004; Swinnen, 2008).

The problem of discrepancy between "liberalization" and "multifunctional goals" discourse and practice, which we have pointed out in the introduction, is that it is not simply empiri- 
DRUŠ. ISTRAŽ. ZAGREB GOD. 21 (2012),

BR. 1 (115)

STR. 219-238

LOVEC, M., ERJAVEC, E.: "BIG BANG"... cal. In fact, the dominant CAP reform discourse is based on a valid epistemic practice - the practice of institutionalized reform process. However, we do doubt that this practice is per se a robust limit of relevant knowledge-claims. The issue here is essentially methodological (Wight, 2006, 31-2; Jackson, 2011, 196-200). By "methodological" we mean the theory of validity of knowledge-claims. The liberal institutional framework applies empiricist methodology which basically universalizes individual pragmatic validity criteria. ${ }^{2}$ There are at least two potential problems with such an approach. Firstly, conventions, enabling the agency to reason about its behavior, may not be "neutral" to practice. Secondly, conventions may not be the limits (determinants) of the practice. The former argument usually divides positive and reflexive epistemologies. Reflexive epistemologies point to the interest biased discourses (or in fact any other social institutions). However, "multifunctional" and "liberal" discourses demonstrate the transformation of the criticism of the old protectionist CAP into a new "dominant" CAP discourse, basically leaving its distributional practice unchanged. This leads to the second problem, indicating that conventions do not limit or simply determine practical struggles, but depend on underlying structural tendencies which find their expression in social institutions (discourses). "The role of political action and policy-making /.../ the way agency is being realized through political action and the deployment of different discursive practices, point on/ the relationship between deepest structural tendencies and policy trends and the way these are constituted in relation to, and mediated through, the agency of individual land managers and other actors" (Potter and Tilzey, 2005, 583).

The first, reflexive point and the second, realist point, are fundamental to critical realism. By observing the transformations and tensions in social institutions, critical realism tries to determine dispositional properties of the objects, approximating a "mind-independent world" (Patomäki and Wight, 2000, 223; Kurki, 2008, 198, 286).

In spite of the "deep" methodological difference between the two frameworks, on the level of concrete methods, both can be pluralist. For our research, we have used academic papers on the enlargement and CAP reform in the observed period, think tank policy papers and analyses, formal statistical data, published and unpublished records of the Ministry of Agriculture, Forestry and Food, of the Governmental Office of Foreign Affairs of the Republic of Slovenia (NTARS 2000), as well as information gathered through interviews with various participants in the negotiating process, including the EC (DG Enlargement, DG Agriculture), member states (national 
(1) TABLE 1

Liberal institutional and critical realist explanatory framework ministries for agriculture in Austria, Germany, Spain, Ireland, the Netherlands, Italy, Great Britain, and Sweden), and candidate countries (Poland, Hungary, Estonia, Cyprus, and Slovenia). The interviews were conducted by one of the authors between September 1998 and December 2002.

Reform

dimensions

Liberal institutional

Critical realist

Globalization

of agriculture

Role of

common

institutions
- Productivity growth increased expenses and negative externalities - New actors, expectations and priorities emerged (environment, global trade)

- Current CAP would produce suboptimal effects: excessive supports, additional productivity increases and policy lock-in. Thus, phasing-out of production based supports and financial discipline were strengthened.

- CAP mechanisms were accommodated to the context of the enlarged EU

- Enlarged Council strengthened the role of EC, common financing triggered pressures for budget stringency
- Strategies of intensive agricultural producers and of owners of capital fixed to agricultural production (land, agricultural machinery etc.) (H1)

- CAP was accommodated in order to prevent redistribution of subsidies to CEEC's semi-substantial agriculture, operating on the basis of low rents and low capital (H2)

- Institutional characteristics of the process were merely a medium for the structural power exerted by the locus od agricultural production dependent capital (H3)

\section{GLOBALIZATION OF AGRICULTURAL WELFARE STATE}

For almost thirty years, in European Communities, agricultural product prices were agreed on the agricultural ministers' level at the beginning of each marketing year. They were sustained above the world prices using mechanisms like tariffs, institutional buy-outs and export subventions. Thus, CAP supported European agricultural production. Yet, effects of the European agricultural welfare state were controversial; subsidies were highly concentrated on the margin of most productive farmers with around two thirds of the subsidies being capitalized in input prices (land, agro-machinery, chemicals). CAP was also redistributing economic resources between European Communities' members with those producing the most (historically, this was France) being CAP beneficiaries (Tracy, 1993).

The overproduction problem was immanent to CAP. Product based supports were increasing output in contrast to a 
DRUŠ. ISTRAŽ. ZAGREB GOD. 21 (2012),

BR. 1 (115)

STR. 219-238

LOVEC, M., ERJAVEC, E.: "BIG BANG"... relatively inelastic demand for food. Lowering of institutional prices, which would be a normal reaction, was politically unacceptable for at least two reasons; there was a gap between highly productive industrial farms and less productive "family farms", with the latter being concentrated in specific regions or member states. Secondly, the shrinking of the agricultural production sector would especially harm the interests related to the scope of the factor use per se (interests of fixed capital). Thus, productivity growth even provoked pressures for higher supports. In the eighties, product surpluses grew into mountains of grain and rivers of milk. Since excessive production had to be financed through the common budget (e.g. export subventions), the eighties saw a dramatic increase in CAP budget costs (Ritson and Harvey, 1997).

Communities' members contributing relatively more than receiving from the common budget, like the United Kingdom, Germany and the Netherlands, faced an additional distributional burden. ${ }^{3}$ Under the influence of the GATT Uruguay Round negotiations, the 1992 MacSharry reform lowered agricultural commodities prices and introduced payments compensating farmers for the revenue lost. The 1992 reform basically fixed part of the supports to the past production and partly neutralized the effects of productivity development on different types and geographies of agro-capital. A larger share of CAP was now financed from the CAP budget (by European taxpayers). ${ }^{4}$

The successful conclusion of the Uruguay Round Agreement on Agriculture (URAA) in 1994 established a "color box" terminology for agricultural policy mechanisms. Export subsidies, tariffs and other price (production) distorting measures ("amber box"), were constrained by limitations and considered to be eventually phased-out. The EU's compensatory payments as well as specific US support schemes ("blue box") were temporarily allowed since they were interpreted as "supports targeting limiting of the production". Investments in rural infrastructure, compensations for specific production practices and other "market non-distorting measures" ("green box") remained unconstrained (Coleman and Tangermann, 1999).

A new global regime, regulating agricultural subsidies and trade, emerged with the political discourse of G7, GATT and OECD regarding the need to contain global negative externalities on behalf of CAP-like protectionist and mercantilist policies (Buckwell and Tangermann, 1997; Moyer and Josling, 2002). However, in practice it was merely accommodating strategic interests of the agro-food industry and of fixed agro-capital to intense productivity growth. Limitations to "trade-distorting" measures speeded up concentration in global agro-food production, processing, distribution and retailing. A- 
DRUŠ. ISTRAŽ. ZAGREB GOD. 21 (2012)

BR. 1 (115),

STR. 219-238

LOVEC, M., ERJAVEC, E. "BIG BANG"... $\frown$ FIGURE Distribution of the CAP budget (financial shares $\%$ of central mechanisms) gricultural commodity prices were now being increasingly determined by specialized highly productive farms (Potter and Tilzey, 2007, 1294, 1296). The 1992 CAP reform, which left the size and the structure of agricultural supports allocation almost unchanged (Garzon, 2007, 28-9), both subsidized the role of European agro-food industry in concentrated global trade networks and preserved the agricultural production related interests of fixed agro-capital.

The Agenda 2000 CAP reform further decreased product prices and increased compensatory payments. It established the "rural development pillar", allocating approximately $10 \%$ of CAP budget funds for agro-environmental targets and rural development programs. The 2003 Mid-Term Review ("Fischler's Reform") decoupled most of the price and production based supports and introduced direct payments schemes - under these schemes, qualifying for the WTO green-box, supports only required to "keep the agricultural land in good condition". In accordance with the EC (2003), post-reform CAP no longer supported farmers for producing beyond the costs recognized by global markets, but only compensated them for extra costs of providing for specific common public goods and positive externalities (Garzon, 2007, 41).

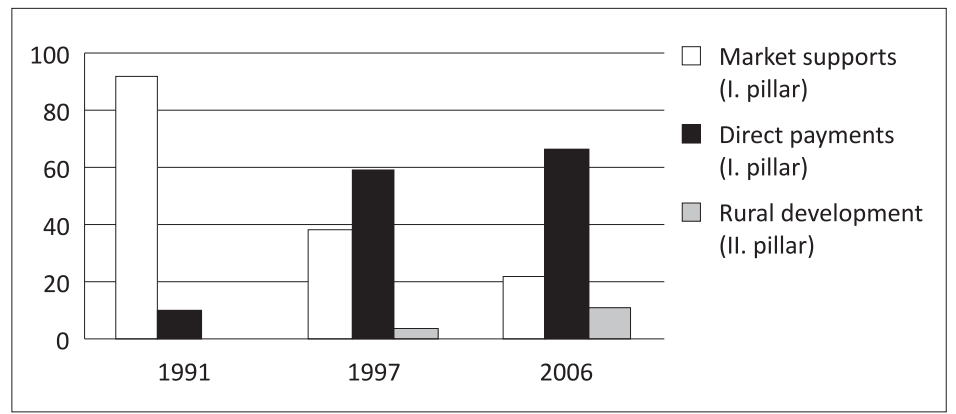

Environmental NGOs became active in the field of CAP reforms in the late eighties. The 1996 BSE and dioxin crises opened the food safety question, several farm lobbies and political parties began to defend the traditional family farm concept (Potter and Lobley, 2004). However, as Schrader demonstrated $(2000,232)$, the reformed CAP was far from being first best policy choice for the declared multifunctional objectives. "Green CAP" was a paradox in itself, since complete phasingout of CAP, now subsidizing farmers to produce and not to produce, would per se provoke the biggest decrease of agricultural pressures on the European environment.

One could still claim that reforms were provoked by the institutional arrangement under which an increasing share of CAP expenses were now financed from the budget. Reformist members (UK, Netherlands, Germany), contributing most to 
DRUŠ. ISTRAŽ. ZAGREB GOD. 21 (2012),

BR. 1 (115)

STR. 219-238

LOVEC, M., ERJAVEC, E.: "BIG BANG".. the common budget, joined by Sweden in 1995, pressured to curb the budget imbalances (Ackrill, 2003; Garzon, 2006). Yet, reforms did little to change the distribution of CAP subsidies and prior to the 2004 enlargement did not even stop the CAP budget growth (Footnote no. 4). In contrast to the institutional argument, member states' priorities basically reflected effects of global productivity developments on the types of their agricultural structures. Between the member states and in their domestic debates, there were increased cleavages between agricultural syndicates with some defending intensive "market" agriculture and others defending traditional and organic agriculture (Potter and Tilzey, 2007, 1297). Decoupling of supports enhanced the market role of intensive producers and payments, targeting multifunctional goals, preserved the rents of fixed capital owners by continuing the employment of production factors like land. ${ }^{5}$ France, with both highly intensive crop farms in the Paris basin and less concentrated production in southern regions, remained a big CAP beneficiary. The UK's extensive landowners heavily benefited from agro-environmental schemes as well (Lowe et al., 2002). These structural characteristics were determining decision-making on CAP reform much more than the overall effects CAP had on the economies of these countries, thus explaining the continuous asymmetries in CAP's effects on EU members.

Agricultural policy developments in OECD countries were similar (e.g. Conservation Security Program under the 2002 US Farm Act; Potter and Tilzey, 2007, 1295; Potter and Lobley, 2004). The URAA had an in-built agenda for further liberalization of national agricultural policies. However, pressures on global and regional marginal agricultural production, instituted by the new global regime, triggered severe discontent. The Cairns Group ${ }^{6}$ demanded for thorough liberalization of agricultural support policies. The Doha Round was launched in January 2001 in Qatar, but negotiations have not led to a successful conclusion. CAP reforms were signaling that at least on the European continent, globalization of agriculture continued regardless.

\section{ENLARGEMENT AND CAP REFORM}

CEEC's agriculture, which was already extensive and underdeveloped, faced additional increases in labor intensity and decreases in agricultural productivity in the 1990s (Gorton and Davidova, 2001). They lost traditional export markets, many workers were driven back to rural areas. At the end of the 1990s, value added per agricultural worker in Poland and Romania was $8 \%$ and $6 \%$ of the EU level (Pouliquen, 2001, 6).

In 1991, the EU and individual CEEC began to sign "European agreements", liberalizing mutual trade. In spite of CEEC's 
DRUŠ. ISTRAŽ. ZAGREB GOD. 21 (2012)

BR. 1 (115)

STR. 219-238

LOVEC, M., ERJAVEC, E.: "BIG BANG"..

(1) TABLE 2

CEEC's agriculture relative abundance and low price of agricultural production factors, the EU's agro-food export to CEEC grew at much faster rates than the import (Table 2). The problem of CEEC's agriculture was the developmental gap between their production structures and global industrial farming. An average Polish dairy farm had three cows! Simultaneously, subsidized intensive production from EU-15 was taking over CEEC's markets. ${ }^{7}$ Trade liberalization and globalization of agro-food networks changed little in terms of structural underdevelopment; incentives to invest in CEEC's farming remained low and shares of semi-substantial farms high. Capital intensive segments of the agro-food industry like food processing were facing greatest pressures (Baker, 2002; Tangermann and Banse, 2000).

\begin{tabular}{lrrrrrrr}
\hline & $\begin{array}{r}\text { GDP PPP } \\
\text { \% of EU-15 } \\
\text { average) }\end{array}$ & $\begin{array}{r}\text { Agri- } \\
\text { GDP } \\
(1988)\end{array}$ & $\begin{array}{r}\text { \% em- } \\
\text { ployed in } \\
\text { agri- } \\
\text { culture* }^{*}\end{array}$ & $\begin{array}{r}\text { Agri-sur- } \\
\text { face }(1997, \\
\text { million ha) }\end{array}$ & $\begin{array}{r}\text { Food in } \\
\text { total con- } \\
\text { sumer } \\
\text { spending* }\end{array}$ & $\begin{array}{r}\text { Agri-trade with } \\
\text { EU-15 (1993/2000, } \\
\text { billion dollars) }\end{array}$ \\
\hline Bulgaria & 24,1 & 14,5 & 13,2 & 6,2 & 42,2 & $-14,3$ & 18 \\
Czech Republic & 60,1 & 4,8 & 5,5 & 4,28 & 21,3 & $-113,3$ & $-621,5$ \\
Estonia & 38 & 7,1 & 7 & 1,2 & 32,7 & $-31,8$ & $-184,3$ \\
Hungary & 52,8 & 5,8 & 6,5 & 6,2 & 34,9 & 621,5 & 530,4 \\
Latvia & 29,2 & 7,4 & 14,4 & 2,52 & 33,3 & $-7,9$ & $-163,4$ \\
Lithuania & 29,5 & 11,3 & 18,4 & 3,5 & 44,4 & 3,3 & -124 \\
Poland & 38,9 & 5,1 & 18,7 & 18,47 & 30,8 & $-254,6$ & $-324,8$ \\
Romania & 26,9 & 18,8 & 45,2 & 14,79 & 38,5 & $-332,9$ & $-135,5$ \\
Slovakia & 48,1 & 4,8 & 6,9 & 2,44 & 26,2 & $-77,5$ & $-192,9$ \\
Slovenia & 71,1 & 3,8 & 9,6 & 0,78 & 20,1 & $-82,6$ & $-237,1$ \\
CEEC & & 7 & 22 & 60,39 & & & \\
EU-15 & & 1,6 & 5 & 134,26 & 15 & & \\
\hline
\end{tabular}

*2000/2001. Source: OECD, 2002; Baker, 2002; O'Callaghan, 2003, 174.

In June 1993, EU heads of states formally agreed on the enlargement criteria. "Copenhagen criteria" ("democratic institutions, market economy, ability to meet market forces of the EU and to fulfill membership obligations including the goals of political, economic and monetary union") reflected the liberal character of the enlargement project (Potter and Tilzey, 2007, 1292). When enlargement entered the agenda, it was argued that CAP would provoke a 15 billion $€$ transfer to CEEC's agriculture, which was more than $70 \%$ of their 1999 agricultural GDP (Swinnen, 2003, 9). This would substantially pressure the CAP budget distribution, provoke further production increases and breaches of WTO commitments (Münch, 2000). Making new member states CAP beneficiaries would produce further policy lock-in (Daugbjerg and Swinbank, 2004, 109). Finally, the EC claimed (2002a) that extensive supports would be suboptimal for modernization of CEEC's agriculture. ${ }^{8}$ 
DRUŠ. ISTRAŽ. ZAGREB GOD. 21 (2012),

BR. 1 (115)

STR. 219-238

LOVEC, M., ERJAVEC, E.: "BIG BANG"...
The Agenda 2000 reform, agreed at the Berlin EU Council in 1999 just before the accession negotiations on agriculture began, further fixed supports to historic yields and production entitlements. In 2000, direct payments represented as much as $69 \%$ (25,6 billion $€$ ) of CAP budget expenses. Falling into the context of the failed Seattle WTO talks, the Agenda 2000 "liberalization" reform was specifically targeting CEEC's accession. Due to the nineties' modest protection levels and economic stress, CEEC's reference quantities for direct payments were relatively low and scattered around numerous small farms whose production in the post-reform period would be further pressured on behalf of the lower institutional prices. However, a vast number of farms still guaranteed substantial CAP budget transfer to CEEC. In accordance with analyses made, the accession of eight CEECs (without Romania and Bulgaria) in the post-Agenda 2000 CAP, would result in a 10 billion $€$ increase in CAP expenses (with direct payments costs representing 65\%) (Münch, 2000, 128; Daugbjerg and Swinbank, 2004, 101).

In the nineties, the debate on the CAP budget gained importance. Since CAP expenses were now financed from the common budget, this could be expected. During the negotiations, member states settled on a narrow financial frame, enforcing future budget stringency. Due to the fact that CAP budget contributions correlated with members' GDPs and CEEC's GDPs were relatively low (Schrader, 2000, 238), candidates were forced to agree on financial constraints to their integration into CAP. Thus, in contrast to the fact that the budget debate did little to change the distribution of funds between the old members or to increase the efficiency of CAP payments, it did curb the allocation of subsidies to future new members.

The 2003 CAP reform continued the phasing-out of price based supports in exchange of now fully decoupled direct single farm payments. With the 2003 reform, direct payments were re-conceptualized into compensations for complying with specific production standards. ${ }^{9}$ The rural development pillar, instituted by the Agenda 2000 reform was strengthened. "Multifunctional paradigm", instituting the imperative of market behavior and only supporting farmers for provision of public goods, was seen as a revolution of traditional CAP (Garzon, 2006; Swinnen, 2008). We have already pointed to the contradictions between multifunctional objectives and CAP mechanisms. What decoupling (introduction of direct payments) de facto provoked, were increased price pressures on CEEC's agriculture and depressed competition for CAP subsidies on the EU level (the latter would be of EU's taxpayers' primary interest). New production standards demanded additional investments from CEEC's farmers. The rural develop- 
DRUŠ. ISTRAŽ. ZAGREB GOD. 21 (2012),

BR. 1 (115)

STR. 219-238

LOVEC, M., ERJAVEC, E.: "BIG BANG".. ment pillar, specifically targeting multifunctional objectives, was not based on EU level tenders but on national programs, demanding for capital intensive rural infrastructure and national co-financing. Already in the nineties, a relatively inefficient utilization of EU's rural development aids to CEEC's agriculture (SAPARD program) demonstrated that the real problem of their rural (agricultural) development were high input and low output prices sustained by EU's agricultural subsidies (Baker, 2002; O'Callaghan, 2003, 182).

After the 2003 reform, the Council of the EU declared (EC, 2003) that "/e/very country or Union has the right to an agricultural policy of its own, provided it is sustainable and avoids or limits trade distortion. The support the EU offers to its farmers is a policy choice, based on an objective of ensuring a sustainable agriculture, in its social, economic and environmental aspects. The reform confirms and acts on that choice, and aims at securing the future of farmers in a changing world in the light of societal demands and international requirements."

In other words, one year before the enlargement, CAP was de facto "nationalized". In accordance with the liberal institutional model, the planned enlargement augmented the will of the European Council and the ability of the Commission to rationalize CAP and to introduce new support targets (Swinnen, 2008). Yet, from the perspective of EU level interest groups (taxpayers, consumers or agricultural producers) there was hardly any evidence of CAP rationalization. Furthermore, the common decision making in the European Council and the common budget did not seem to have been the $\mathrm{u}$ nique setting, autonomously influencing the "rationalization of the CAP", since nationalization of the CAP budget expenses merely reflected the structural differences between the agriculture of the old and of the new Europe. Contrary to intensive producers or fixed capital owners in EU-15, CEEC's agriculture was (on average) underdeveloped, bound by regional and global agro-food networks, which were putting downward pressures on its potential rents. This made them a weak voice, enabling post-enlargement CAP to be established on the basis of national budget effects and national multifunctional targets, on behalf of which the old members were able to sustain the asymmetrical capitalization levels of their agricultural production based capital. In the following chapter, this argument will be extended in order to explain the whole accession negotiations process.

\section{ACCESSION NEGOTIATIONS}

Early in 1998 ten candidates began to "screen" the 31 chapters of the acquis communitaire. The acquis of the seventh chapter (on agriculture) consisted of common market organizations, 
DRUŠ. ISTRAŽ. ZAGREB GOD. 21 (2012), BR. 1 (115)

STR. 219-238

LOVEC, M., ERJAVEC, E.: "BIG BANG"... governing individual products' market and support regimes, of veterinary, phyto-sanitary and food safety standards. In 1999, when candidates were drafting their formal positions, the EU Berlin summit settled the Agenda 2000 reform, increasing the importance of direct payments. A couple of months later, negotiations on the agriculture chapter officially began. During several rounds of bilateral and multilateral sessions, the EU's and candidates' representatives (EU was not represented by DG enlargement but by Unit for Enlargement delegated from DG Agriculture) exchanged their "common positions" and "additional clarifications". Many issues were tackled at the parallel informal "technical meetings".10

Following the Agenda 2000 reform, candidates were pressuring the EC to start the talks on reference quantities and quotas, which were important for their direct payments. However, as we have tried to demonstrate in the above section, accession of CEECs into the post-Agenda 2000 CAP was still perceived as too expensive. Reformists saw the solution in a complete phasing-out of direct payments, which was unacceptable for the majority of the member states. Thus, the EC was postponing the debate. In 2000 and 2001, the progress of negotiations was only spasmodic. In its 2000 and 2001 reports, the EC concentrated on problems related to CEEC's acquis implementation. The 2002 report signaled serious delays in establishment of the Integrated Administration and Control System (IACS) ${ }^{11}$ (Baker, 2002).

Accession negotiations were clearly highly institutionalized. However, even the fact that the candidates were pressured to comply with the acquis did not seem to specifically reflect the role of EU's institutional resources but was essentially related to CEEC's agricultural structures. For numerous semi-subsistence farms with low capital, EU standards represented high costs (Zellei et al., 2005). The EU supported agricultural modernization through pre-accession rural development programs but the underlying effect of this carrot and stick approach was soft deagrarization of CEECs. This reflected the fundamental structural characteristics of the candidates' agricultural production: their farmers resembled more self-sustaining agricultural workers than agro-capital owners. The abundance of agricultural production factors was paradoxically not strengthening but weakening the CEEC's negotiating position. In EU-15, the role of agricultural lobbies was different. They publicly argued that CEEC's agricultural products, non-complying with EU standards, will flood EU markets. Since there were presidential and parliamentary elections in France and Germany in 2002 with CAP figuring as an important issue, these claims were mobilizing the pressure on the final agreement on post-enlargement CAP. 
DRUŠ. ISTRAŽ. ZAGREB GOD. 21 (2012), BR. 1 (115),

STR. 219-238

LOVEC, M., ERJAVEC, E.: "BIG BANG"..
In its enlargement strategy, published in January 2002 (EC, 2002a), the EC proposed direct payments to be only gradually augmented in new member states (from $25 \%$ in 2004 to 100\% in 2013). Production between the years 1995 and 1999 was proposed as a reference for direct payments. On behalf of the problems with implementation of IACS, candidates were offered the possibility of Single Area Payment Scheme (SAPS). ${ }^{12}$ There was not much reason for candidates to be satisfied with the proposal. During the reference period, their production was at the lowest levels. The EC's proposal was depressing the potential growth of their agricultural sectors. Even the SAPS scheme, which was presumably lessening bureaucratic pressures on their agriculture, would in practice demotivate potential production strategies of individual farmers due to the flat-rate nature of payments. Simultaneously, DG Agriculture presented a study (EC, 2002b) claiming that the economic position of candidates' agriculture would be improved after the enlargement even if direct payments were not granted (with the exception of Cyprus and Slovenia). The enlargement strategy demonstrated two things: the EC was well aware that candidates would comply with only the nominally improved position of their agriculture. And secondly, the slow progress was due to the disagreement on direct payments between the member states (or better said, between fixed capital owners and intensive producers) in which CEECs were, due to their poor production structures, relatively unimportant actors.

From April to the end of October 2002, negotiations on quotas and reference quantities continued. Candidates tried with direct bilateral negotiations with individual member states. In the fourth week of October 2002, French president Jacques Chirac and German chancellor Gerhard Schroeder made an agreement which enabled the conclusion of negotiations. They decided that direct payments will remain, but the overall expenditures in the EU-25 on market interventions and direct payments would be kept below the 2006 figure in real terms during the 2007-2013 financial perspective period.

The Franco-German agreement, formalizing budget discipline and past production based subsidies as a framework for CAP based redistribution, was endorsed at the October 2002 Brussels European Council (Daugbjerg and Swinbank, $2004,101)$. Compared to the initial proposal of the EC, the final compromise agreement, prepared by the presiding state (Denmark), provided additional rural development funds for Poland, the Czech Republic, Slovakia, and Slovenia. Candidates were allowed to top-up direct payments (either from national budgets or by using less than $20 \%$ part of the nation- 
DRUŠ. ISTRAŽ. ZAGREB GOD. 21 (2012),

BR. 1 (115),

STR. 219-238

LOVEC, M., ERJAVEC, E.: "BIG BANG".. al rural development funds in the years 2004-2006). The maximum direct payment levels, including top-ups, ranged from $55 \%$ in 2004 to $100 \%$ in 2010 . Some agricultural sectors in Slovenia and the Czech Republic were allowed higher top-ups due to higher pre-enlargement supports. Where candidates' contributions to the CAP budget would exceed their benefits during the first years of accession, additional supports were granted (Swinnen, 2003, 8). This reflected both specific characteristics of candidates' agricultural sectors and their conformity with the nationalist accession negotiations discourse.

The chapter on agriculture was de facto closed just prior to the heads of states meeting in Copenhagen on 12 and 13 December 2002 (Baker, 2002, 12) when a final agreement on enlargement was reached. During 2002, DG Agriculture was already working on the 2003 CAP reform, settled in the year between the successful conclusion of accession negotiations and the accession itself (Dagbjerg and Swinbank, 2004, 103).

\section{DISCUSSION}

Planned enlargement was expected to increase direct CAP costs, tensions related to budget distribution and other policy related negative externalities. In accordance with both the liberal institutional model and the EU's official discourse, this provoked rationalization of the CAP and establishment of the new multifunctional targets. Common decision making and common policy financing, being the central characteristics of the institutional setting, specifically influenced pre-enlargement reforms.

In our analysis, we have tried to point out the weaknesses of such a perspective. Productivity growth was not threatening farmers per se, since the revenues on their physical work were comparably low, but capital fixed to agricultural production, whose supply would dramatically increase with falling aggregate production activities, influencing the prices and returns of agricultural assets and production inputs, was. Several intensive producers supported CAP liberalization, since they would benefit from the decreased input prices and agricultural product supply. In accordance with our first hypothesis, reforms, fixing subsidies to past production, satisfied the essential interests of both types of agro-capital.

In contrast to West European agricultural production structures, CEEC's farms were, on average, semi-substantial with low levels of factor capitalization. Limitations to distribution of CAP subsidies to the future new members and de facto nationalization of CAP support was our second hypothesis, claiming that accommodation of CAP to the enlargement was 
DRUŠ. ISTRAŽ. ZAGREB GOD. 21 (2012), BR. 1 (115),

STR. 219-238

LOVEC, M., ERJAVEC, E. "BIG BANG".. basically determined by the geography of agricultural production structures. The ad hoc policy and institutional arrangements curbing the potential supports' redistribution demonstrated that common institutions only played an instrumental role (our third hypothesis). The majority of the formal messages (discourses) on the reform and enlargement processes seemed to be simply targeting audiences, historically taxed by CAP due to their high transaction costs for effective engagement in policy reform. The weak role of the European taxpayers and consumers, whose interests should be defended by the EC, pointed to the importance of the notion of "structural power".

With successful integration, living and working conditions were not worsened for many of the CEEC's farmers, especially in sectors such as livestock products, coarse grains, fruits and vegetables. However, prior to the enlargement, the agricultural policy "tax" on CEEC's economies was approximately half of the EU average. In contrast to inflated food prices and agricultural production input prices, prices of the raw agricultural product remained relatively low after the enlargement. Thus, opportunity costs for CEEC's farmers to leave the agricultural business were substantially increased, which sometimes improved the position of those remaining in business. Yet, in contrast to the fact that the new members' consumers extensively financed their accession into CAP (Table 2, food in total consumer spending), the biggest beneficiary of their accession was the agro-food industry based in Western Europe. In EU members like Slovenia, self-sustainability in agricultural production fell to historically low levels. Such evolution was something that was not unexpected before the enlargement (Schrader, 2000, 238; O'Callaghan, 2003, 180; Swinnen, 2003).

In contrast to the enlargement effects, the candidates' overall formal satisfaction with accession agreements evidently pointed towards the limitations of conventionalism (empiricism) in theoretical perspectives. Conventions are essentially instrumental social institutions. This is important when considering the developments of the contemporary CAP, which seems to be fundamentally shaped by the budget discipline principle that was instituted in 2002. In 2006, the total additional expenditures for agriculture (the "costs of enlargement") were 3,9 billion $€$ (Swinnen, 2003, 7-9). The 2006-2013 CAP budgets were fixed at the 2006 level with only a $1 \%$ nominal yearly increase allowed. Since direct payments for new members were being phased-in during the same period, it was expected that this would provoke breaches to budgetary limits. In 2004 and 2005, olive oil, cotton, tobacco and sugar supports were decoupled. In 2008 the Health Check reform 
DRUŠ. ISTRAŽ. ZAGREB GOD. 21 (2012), BR. 1 (115)

STR. 219-238

LOVEC, M., ERJAVEC, E.: "BIG BANG"... decoupled most of the remaining market supports. Due to the budget discipline provision, shares of direct payments were modulated into the rural development pillar, which was not bound by budget growth limitations and where effective supports were enhanced through national co-financing. Such developments demonstrated the strengthening of the role of intensive producers, pressuring for liberalization of supports regime on the EU's domestic market, and the strategies of localized (nationalized) agro-capital for preserving the rents by commoditizing specific extensive production practices. In spite of their extensive agricultural production factor resources, the recent "liberalization" and "extensification" of CAP have paradoxically further weakened the position of new members' agriculture in the EU's and global agro-food chains, pointing towards the need to study CAP beyond its institutional elements.

\section{NOTES}

1 Central and Eastern European candidate countries: Poland, Hungary, Czech Republic, Slovakia, Slovenia, Estonia, Lithuania, Latvia. Malta and Cyprus negotiated their accession together with CEEC-8. Bulgaria and Romania are taken into account in statistics on CEEC. All statistics are from the period of accession negotiations.

2 This methodological practice is commonly referred to as positivist, with positivism being a philosophy of science (Jackson, 2011, 69-71).

${ }^{3}$ Additional because most of them were also net food importers which meant that CAP was already a negative tax for their economies.

4 Following Schrader's calculation (2000, 238), between the 1986-8/ 1996-8 periods, CAP transfer from EU consumers dropped from 84 to 52 billion ECU and trasnfer from taxpayers to farmers increased from 22,5 to 58 billion ECU.

${ }^{5}$ In the nineties, shares of rented agricultural land ranged between $34 \%$ in United Kingdom to 65\% in France (EU-15 average was 41\%). Shares were generally increasing.

613 of 20 world's biggest agricultural products exporting countries (exempting EU and US, the biggest exporters).

7 Hungarian beef and pork production declined for 10\% during 1996-2000 (in 1997, quarter of production was exported in Germany and other EU members) (O'Callaghan, 2003, 175). Prior to accession, some CEECs were increasing protection measures but on average, these remained under EU levels. EU product support estimate average (PSE) was 38\% in 2000 and PSE of Hungary, Poland, Slovakia, Czech Republic and Latvia was 15-25\% (Baker, 2002).

8 Semi-subsistence farms would tend to treat direct payments as household income, low productivity and hidden unemployment would persist (Dagbjerg and Swinbank, 2004, 103).

9 If producing, 18 "cross-compliance" requirements, related to environmental protection, food safety and animal health and welfare, had to be respected in order to apply for direct payments. 
DRUŠ. ISTRAŽ. ZAGREB GOD. 21 (2012),

BR. 1 (115),

STR. 219-238

LOVEC, M., ERJAVEC, E.: "BIG BANG"..
10 There were 32 such meetings for Slovenia in four and a half years of accession negotiations. They were most frequent during the first and last year of negotiations. Altogether there were almost 100 technical meetings of various forms.

11 The IACS system is the mechanism by which producers claim their subsidies.

12 Financial rights would be established on the basis of agreed base areas, average yields, and eligible cattle and sheep numbers. These rights would then be disbursed on a flat-rate basis, over the entire agricultural area (Dagbjerg and Swinbank, 2004, 104).

\section{REFERENCES}

Ackrill, R. W. (2003), EU Enlargement, the CAP and the Cost of Direct Payments: A Note. Journal of Agricultural Economics, 54 (1): 73-78. doi:10. 1111/j.1477-9552.2003.tb00049.x

Baker, D. (2002), Agriculture in the EU's Eastern Enlargement - Current Status for CEECs, Report nr. 144, Fødevareøkonomisk Institut: København.

Buckwell, A. and Tangermann, S. (1997), The CAP and Central and Eastern Europe. In: C. Ritson and D. R. Harvey (eds.), The Common Agricultural Policy (pp. 307-342), 2nd edition. CAB International.

Buckwell, A. and Tangermann, S. (1999), Agricultural Policy Issues of European Integration: The Future of Direct Payments in the Context of Eastern Enlargement and the WTO'. MOCT-MOST: Economic Policy in Transitional Economies, 9 (3): 229-254. doi:10.1023/A:1009512503787

Coleman, W. D. and Tangermann, S. (1999), The 1992 CAP Reform, the Uruguay Round and the Commission: Conceptualizing Linked Policy Games. Journal of Common Market Studies, 37 (3): 385-405. doi:10. 1111/1468-5965.00170

Cunha, A. (2004), A Role for Direct Payments? The Doha Round, EU Enlargement and Prospects for CAP Reform. In: A. Swinbank and R. Tranter (eds.), A Bond Scheme for CAP Reform (pp. 149-167), Centre for Agricultural Strategy, The University of Reading, UK, CABI Publishing. doi:10.1079/9780851997445.0149

Daugbjerg, C. (1997), Farmers' Influence on East-West Integration in Europe: Policy Networks and Power, TKI Working Papers on European Integration and Regime Formation, South Jutland University Press.

Daugbjerg, C. and Swinbank, A. (2004), The CAP and EU Enlargement: Prospects for an Alternative Strategy to Avoid the Lock-in of CAP Support. Journal of Common Market Studies, 42 (1): 99-119. doi:10.1111/j.0021-9886.2004.00478.x

European Commission (2002a), Enlargement and Agriculture: Successfully Integrating the New Member States into the CAP. Issues Paper and Annex, Brussels: European Commission.

European Commission (2002b), Impact Assessment of the Mid-Term Review Proposals on Agricultural Markets and Income in the EU-15 and EU-25 2004-2009, Brussels: European Commission.

European Commission (2003), A Long Term Perspective for Sustainable Agriculture, COM(2003)23 final, Brussels. 
DRUŠ. ISTRAŽ. ZAGREB GOD. 21 (2012), BR. 1 (115)

STR. 219-238

LOVEC, M., ERJAVEC, E.: "BIG BANG"..
Garzon, I. (2006), Reforming the Common Agricultural Policy: History of a Paradigm Change, Basingstoke, New York, Palgrave Macmillan. doi:10. $1057 / 9780230626577$

Garzon, I. (2007), A Changing Global Context in Agricultural Policy. Policy Paper, Notre Europe 2007.

Gorton, M. and Davidova, S. (2001), The International Competitiveness of CEEC Agriculture. The World Economy, 24 (2): 185-200. doi:10. 1111/1467-9701.00351

Jackson, P. T. (2011), The Conduct of Inquiry in International Relations, Routledge.

Kurki, M. (2008), Causation in International Relations: Reclaiming Causal Analysis, Cambridge, Cambridge University Press.

Lowe, P., Buller, H. and Ward, N. (2002), Setting the Next Agenda? British and French Approaches to the Second Pillar of the Common Agricultural Policy. Journal of Rural Studies, 18 (1): 1-17. doi:10.1016/S07430167(01)00025-0

Moyer, W. and Josling, T. (2002), Agricultural Policy Reform. Politics and Process in the EU and US in the 1990s, Burlington, Ashgate.

Münch, W. (2000), Effects of CEEC-EU Accession on Agricultural Markets in the CEEC and on Government Expenditure. In: Ministry of Agriculture, Forestry and Food (MAFF), Internal Sources on Negotiations in the Chapter Agriculture, Ljubljana: MAFF.

Negotiating Team for the Accession of the Republic of Slovenia to the EU (NTARS), (2000), Negotiating Positions of the Republic of Slovenia on Accession to the European Union, Ljubljana, Government Office for European Affairs.

O'Callaghan, B. A. (2003), The Economics of European Integration, Palgrave Macmillan, Houndmills, Bashingstoke, Hampshire.

OECD (2002), Agricultural Policies in Transition Countries: Trends in Policies and Support, Paris.

Patomäki, H. and Wight, C. (2000), After Postpositivism? The Promises of Critical Realism. International Studies Quarterly, 44 (2): 213-237. doi:10.1111/0020-8833.00156

Potter, C. and Lobley, M. (2004), Agricultural Srestructuring and State Assistance: Competing or Complementary Rural Policy Paradigms? Journal of Environmental Policy and Planning, 6 (1): 3-18. doi:10. 1080/1523908042000259659

Potter, C. and Tilzey, M. (2005), Agricultural Policy Discourses in the European Post-Fordist Transition: Neoliberalism, Neomercantilism and Multifunctionality. Progress in Human Geography, 29 (5): 581-600. doi:10.1191/0309132505ph569oa

Potter, C. and Tilzey, M. (2007), Agricultural Multifunctionality, Environmental Sustainability and the WTO: Resistance or Accommodation to the Neoliberal Project for Agriculture? Geoforum, 38 (6): 1290-1303. doi:10.1016/j.geoforum.2007.05.001

Pouliquen, A. (2001), Competitiveness and Farm Incomes in the CEEC Agri-Food Sectors, Independent Study Requested by the DG Agriculture. European Commission: Brussels. 
DRUŠ. ISTRAŽ. ZAGREB GOD. 21 (2012),

BR. 1 (115),

STR. 219-238

LOVEC, M., ERJAVEC, E.: "BIG BANG"..
Ritson, C. and Harvey, D. R. (1997), The Common Agricultural Policy. 2nd edition. CAB International.

Schrader, J.-V. (2000), CAP Reform, the Berlin Summit, and EU Enlargement. Intereconomics, 35 (5): 231-242. doi:10.1007/BF02930139

Swinnen, J. F. M. (2003), The EU Budget, Enlargement and Reform of the Common Agricultural Policy and the Structural Funds, Paper presented at the Land Use Policy Group (LUPG) Conference on "Future Policies for Rural Europe", 12-14 March 2003, Brussels.

Swinnen, J. F. M. (2008), The Perfect Storm. The Political Economy of Fischler Reforms of Common Agricultural Policy, Brussels, Centre for European Policy Studies.

Tangermann, S. and Banse, M. (eds.) (2000), Central and Eastern European Agriculture in an Expanding European Union, Wallingford, CAB International.

Tracy, M. (1993), Agricultural Policy in the European Union and Other Market Economies, La Hutte, Agricultural Policy Studies.

Wight, C. (2006), Agents, Structures and International Relations: Politics as Ontology, Cambridge, Cambridge University Press.

Zellei, A., Gorton, M. and Lowe, P. (2005), Agri-Environmental Policy Systems in Transition and Preparation for EU Membership. Land Use Policy, 22 (3): 225-234. doi:10.1016/j.landusepol.2003.09.008

\section{"Veliki prasak" proširenja i reforma Zajedničke poljoprivredne politike}

Marko LOVEC, Emil ERJAVEC

Biotehnički fakultet, Ljubljana

U članku se analizira utjecaj proširenja iz 2004. i pristupnih pregovora od 1998. do 2002. na reformu Zajedničke poljoprivredne politike (ZPP). Za razliku od prevladavajućih političko-ekonomskih modela liberalnog institucionalizma, koji ZPP reforme iz vremena prije proširenja objašnjavaju negativnim trgovinskim vanjskim učincima, zajedničkim proračunskim rashodima i specifičnom ulogom koju je odigrao zajednički institucionalni okvir predlaže se kritičko-realistički model tumačenja. U skladu s modelom, reforme su olakšane zbog sukobljenih interesa i razlika u kreditnoj sposobnosti povezanoj s poljoprivrednom proizvodnjom $u$ zemljama članicama i zemljama kandidatkinjama. Kapacitet agrokapitala definiran je usporedbom struktura poljoprivredne proizvodnje, koje su u slučaju starih država članica održavale visoke razine fiksnoga kapitala, a koje su u slučaju zemalja kandidatkinja, u prosjeku, bile nerazvijene i potkapitalizirane. Model podupire empirijska analiza reforme ZPP-a i procesa pristupnih pregovora.

Ključne riječi: Zajednička poljoprivredna politika, proširenje, CEEC (zemlje Srednje i Istočne Europe), kritički realizam 